\title{
Physical changes associated with the onset of precocious puberty in rats after treatment with PMSG*
}

\author{
Deborah M. Everard, Nancy J. Rothwell $\dagger$, M. J. Stock $\dagger$ and \\ Catherine A. Wilson \\ Departments of Obstetrics \& Gynaecology and $\uparrow$ Physiology, St George's Hospital Medical School, \\ London SWI7 ORE, U.K.
}

\begin{abstract}
Summary. Body dimensions, composition, oxygen consumption and core temperature were measured in 2 groups of immature rats treated with PMSG. The first group weighed over $60 \mathrm{~g}$ on Day 27 of life and responded to PMSG treatment by ovulating; the second group weighed less than $60 \mathrm{~g}$ and did not ovulate after PMSG. Body composition, expressed as a percentage of body weight, was identical in the two groups, but growth rate, oxygen consumption and body temperature were all lower in the lighter animals. Oxygen consumption and body temperature were manipulated by altering temperature (i.e. 5,22 and $30^{\circ} \mathrm{C}$ ) or by hyperphagia, and a positive correlation was found between body temperature and the occurrence of ovulation.
\end{abstract}

\section{Introduction}

Immature rats treated with 5 i.u. PMSG on Day 27 of life ovulate 3 days later, but only if they weigh more than $60 \mathrm{~g}$ on the day of injection (Wilson \& Endersby, 1979). Rats weighing over $60 \mathrm{~g}$ and under $60 \mathrm{~g}$ all showed a preovulatory rise in plasma LH levels on the afternoon 2 days after injection, but the animals weighing $<60 \mathrm{~g}$ possessed a pleiomorphic form of LH (ter Haar \& Wilson, 1978).

Several reports have shown that the onset of the first ovulation in untreated rats is inversely correlated with body weight (Wilen \& Naftolin, 1978; Merry \& Holehan, 1979; Gentry \& Wade, 1980). This relationship has been modified to show that the age of vaginal opening and first ovulation are quadratically correlated to growth rates (Glass, Harrison \& Swerdloff, 1976), and a correlation has also been noted between vaginal opening and body fat content (Frisch, Hegsted \& Yoshinaga, 1975, 1977). However, the latter observation was not supported by the findings of Glass, Dahms \& Swerdloff (1979), and Ramaley (1981) has suggested that body protein content is more important for the normal timing of vaginal opening and the onset of ovulation.

For these reasons, we have attempted to determine whether the varied responses to PMSG in rats weighing $<60$ or $>60 \mathrm{~g}$ are related to differences in body size and/or composition. In addition, metabolic rate and body temperature have been compared in the two groups of rats since these may also influence the occurrence of ovulation (see Frisch, 1979, 1980).

\section{Materials and Methods}

Animals. Sprague-Dawley female rats taken from litters standardized to 12 (Bantin \& Kingman, Hull, Yorkshire) were maintained from Day 21 of life at $22^{\circ} \mathrm{C}(12 \mathrm{~h} \mathrm{light} / 12 \mathrm{~h}$ dark cycle;

* Reprint requests to Dr C. A. Wilson. 
lights on $06: 00 \mathrm{~h}$ ) and allowed a pelleted stock diet (SB 441, Dixon) and water ad libitum, unless otherwise stated.

Experimental procedures. In Exp. 1, animals were divided into two groups according to whether they weighed $>60$ or $<60$ g on Day 27 of life. They were killed on this day and nose to anus length was measured and the left tibia was dissected and measured. The carcasses were degutted and the composition determined by chemical analysis.

In Exp. 2, rectal temperature and oxygen consumption $\left(V_{2}\right)$ were measured on Day 27 in rats that were $>$ or $<60 \mathrm{~g}$ in weight. The temperature was taken at $12: 00 \mathrm{~h}$ and then daily at this time on Days 28 and 29.

In Exp. 3, the rats were allocated to one of 4 groups. Group I rats were maintained from Day 21 on pelleted stock diet at $22^{\circ} \mathrm{C}$ (control). Rats in Group II were also kept at $22^{\circ} \mathrm{C}$, but allowed a choice of highly palatable food items (cafeteria diet : see Rothwell \& Stock, 1982a) in addition to the stock diet from Day 21. Group III rats were maintained on pelleted stock diet at $22^{\circ} \mathrm{C}$ from Day 21 , but on Day 27 were transferred to a warm environment $\left(30^{\circ} \mathrm{C}\right)$ (warm-adapted). Group IV rats were maintained for 10 days on pelleted stock diet at $5^{\circ} \mathrm{C}$ from Day 21 (cold-adapted).

On Day 27, all the rats were weighed and in Groups I, II and III those weighing $<60 \mathrm{~g}$ were injected s.c. with 5 i.u. PMSG (Folligon; Intervet). All the rats (whether $>$ or $<60 \mathrm{~g}$ ) in Group IV were treated with 5 i.u. PMSG. On Day 29, rectal temperature was measured in all the rats and resting $\mathrm{VO}_{2}$ was determined in those weighing $<60 \mathrm{~g}$ in Groups I, II and IV. $\mathrm{VO}_{2}$ was not measured in the $<60 \mathrm{~g}$ rats of Group III and so it was measured in another set of rats treated in an exactly similar manner as those in Group III; however, these rats all weighed $>60 \mathrm{~g}$ on Day 27. On Day 30, the rats were killed, the oviducts were dissected and the occurrence of ovulation was assessed by counting the ova under a dissecting microscope.

Body composition. The degutted carcasses were freeze-dried to constant weight before homogenizing. Aliquants were taken for determination of fat content by gravimetric analysis after overnight Soxhlet extraction with petroleum ether (b.p. 60-80), nitrogen content by the Kjeldahl method using the Kjeltec System 1 (Oser, 1965) and energy density by ballistic bomb colorimetry (Miller \& Payne, 1959). Protein content was calculated as nitrogen content $\times 6 \cdot 25$.

Oxygen consumption. The $\mathrm{VO}_{2}$ was measured in a closed circuit respirometer (Stock, 1975) at thermoneutrality $\left(29^{\circ} \mathrm{C}\right)$ during the daytime $(08: 00-18: 00 \mathrm{~h})$. Values were taken only when the animals were resting and have been expressed as $\mathrm{ml} / \mathrm{min} / \mathrm{kg}(\mathrm{W})^{0.75}$.

Statistical analysis. Values are presented as means \pm s.e.m. Statistical differences in Tables 1 and 2 were assessed using Student's $t$ test for unmatched data with two-tailed probabilities, and in Table 3 Scheffe's test for significance of difference was used after analysis of variance of all the groups. The significance of difference in number of rats ovulating (also Table 3) was found using Fisher's Tables. For the growth rates, significance was calculated after analysis of covariance.

\section{Experiment 1}

\section{Results}

The average body weights of the rats weighing $>$ or $<60 \mathrm{~g}$ differed significantly by at least $10 \mathrm{~g}$. Body length (nose-anus), tail length and growth rates (calculated over Days 21-29) were all reduced in the $<60 \mathrm{~g}$ rats (Table 1 ), but tibia length was similar for both groups. Rats weighing $<60 \mathrm{~g}$ also had significantly lower fat, water, protein and total energy contents, but the proportional carcass composition was similar for both groups, since the percentage values of water, fat and protein and energy density did not differ significantly.

\section{Experiment 2}

Resting $\mathrm{VO}_{2}$, expressed as the rate per animal, or the rate corrected for body size, was significantly lower in the $<60 \mathrm{~g}$ rats on Day 27 (Table 2) than in those weighing $>60 \mathrm{~g}$. Rectal temperature was also reduced in the $<60 \mathrm{~g}$ rats on Days 27,28 and 29 of life. 
Table 1. Body size, composition and growth rate of rats weighing over and under $60 \mathrm{~g}$ on Day 27 of life

\begin{tabular}{|c|c|c|}
\hline & Group $1(>60 \mathrm{~g})$ & Group $2(<60 \mathrm{~g})$ \\
\hline No. of rats & $8-13$ & 12 \\
\hline Body wt on Day $27(\mathrm{~g})$ & $64 \cdot 6 \pm 1 \cdot 0$ & $53.0 \pm 0.96^{* * * *}$ \\
\hline Nose-anus length $(\mathrm{cm})$ & $13.9 \pm 0.2$ & $12 \cdot 7 \pm 0 \cdot 1 * * * *$ \\
\hline Tail length $(\mathrm{cm})$ & $9 \cdot 3 \pm 0 \cdot 1$ & $8 \cdot 2 \pm 0 \cdot 1^{* * * *}$ \\
\hline Tibia length $(\mathrm{cm})$ & $2 \cdot 3 \pm 0.04$ & $2 \cdot 3 \pm 0.06$ \\
\hline Growth rate (g/day) & $2 \cdot 8 \pm 0.07$ & $2 \cdot 08 \pm 0.08^{* *}$ \\
\hline Body water $(\mathrm{g})$ & $35.9 \pm 0.5$ & $29 \cdot 5 \pm 0 \cdot 7^{* * *}$ \\
\hline Body water $(\%)$ & $71.9 \pm 0 \cdot 2$ & $72 \cdot 1 \pm 0 \cdot 3$ \\
\hline Body fat $(g)$ & $4 \cdot 1 \pm 0 \cdot 2$ & $3 \cdot 4 \pm 0 \cdot 2^{*}$ \\
\hline Body fat $(\%)$ & $8 \cdot 3 \pm 0.4$ & $8.4 \pm 0.4$ \\
\hline Body protein (g) & $8.4 \pm 0.2$ & $6 \cdot 8 \pm 0 \cdot 1^{* * *}$ \\
\hline Body protein $(\%)$ & $16 \cdot 9 \pm 0 \cdot 3$ & $16 \cdot 7 \pm 0.3$ \\
\hline Energy content $(\mathrm{kJ})$ & $358 \pm 9$ & $315 \pm 14^{*}$ \\
\hline Energy content $(\mathrm{kJ} / \mathrm{g}$ dry tissue $)$ & $25 \cdot 5 \pm 0 \cdot 67$ & $27 \cdot 6 \pm 1 \cdot 26$ \\
\hline
\end{tabular}

Values are mean \pm s.e.m.

Significance of difference between Groups 1 and $2:^{*} P<0.05 ;{ }^{* *} P<0.02 ;{ }^{* *} P<0.01 ;{ }^{* * * *} P<0.001$,

$\dagger$ Calculated as the linear regression of weight on age over Days 21 to 29 .

Table 2. Resting oxygen consumption and rectal temperature of rats weighing over $60 \mathrm{~g}$ and under $60 \mathrm{~g}$ on Day 27

\begin{tabular}{|c|c|c|}
\hline & Group $1(>60 \mathrm{~g})$ & Group $2(<60 \mathrm{~g})$ \\
\hline Body wt on Day $27(\mathrm{~g})$ & $67 \cdot 7 \pm 0.5$ & $57.7 \pm 0.5^{* *}$ \\
\hline $\mathrm{ml} / \mathrm{min}$ & $\begin{array}{l}1 \cdot 60 \pm 0.03 \\
12 \cdot 5 \pm 0 \cdot 3\end{array}$ & $\begin{array}{l}1 \cdot 30 \pm 0.03^{* *} \\
11 \cdot 4 \pm 0.02^{*}\end{array}$ \\
\hline Rectal temperature $\left({ }^{\circ} \mathrm{C}\right)$ & & \\
\hline $\begin{array}{l}\text { Day } 27 \\
\text { Day } 28 \\
\text { Day } 29\end{array}$ & $\begin{array}{l}38.7 \pm 0.1 \\
38 \cdot 5 \pm 0 \cdot 1 \\
38.6 \pm 0.1\end{array}$ & $\begin{array}{l}37.9 \pm 0 \cdot 1^{*} \\
38.0 \pm 0 \cdot 1^{*} \\
38.1 \pm 0.1^{*}\end{array}$ \\
\hline
\end{tabular}

Values are mean \pm s.e.m. for $n=12\left(\mathrm{Vo}_{2}\right)$ or $n=16$ (temperature).

Significance of difference between Groups 1 and $2:{ }^{*} P<0.01,{ }^{* *} P<0.001$.

\section{Experiment 3}

All the rats in Exp. 3 showed similar patterns of weight gain, and body weights did not differ significantly between the groups on Days 27 or 30 . (Table 3). On Day 29 (the day of the expected preovulatory $\mathrm{LH}$ surge in PMSG-treated rats), resting $\mathrm{Vo}_{2}$ was significantly elevated in rats in Groups II and IV (17 and $21 \%$ respectively; see Table 3 ). Unfortunately, $\mathrm{VO}_{2}$ measurements were not made on Group III rats (warm-adapted). Therefore another group of rats of the same age were ordered but all of them weighed $>60 \mathrm{~g}(82 \cdot 25 \pm 2.9)$ on Day 27 . In spite of this, we measured the $\mathrm{VO}_{2}$ on Day 29 in a control group and a group kept at $30^{\circ} \mathrm{C}$ for 4 days. The results were as expected for animals kept in a thermoneutral environment (Kleiber, 1961) and showed an $11 \%$ reduction in $\mathrm{VO}_{2}$ (controls $15.6 \pm 0.32 \mathrm{ml} / \mathrm{min} / \mathrm{W}^{0.75}(\mathrm{~N}=6)$; warm-adapted $13.86 \pm 0.54 \mathrm{ml} / \mathrm{min} / \mathrm{W}^{0.75}(\mathrm{~N}=$ 6) $(P<0.05))$. On Day 29 , rectal temperature was increased in the Group II and Group III rats but was similar in rats in Group I and IV. On Day 30, ovulation occurred in $28 \%$ of control rats after injection of PMSG, but this was increased to $73 \%$ in rats in Group II and $67 \%$ in Group III rats but only one Group IV rat ovulated. Exposure to $5^{\circ} \mathrm{C}$ for 10 days did not prevent ovulation in PMSGtreated rats weighing $>60 \mathrm{~g}\left(5 / 5\right.$ ovulated at $5^{\circ} \mathrm{C} ; 17 / 19$ ovulated at $\left.22^{\circ} \mathrm{C}\right)$. There was no significant difference in the number of ova shed in the ovulating rats from any of the groups. 
Table 3. Resting $\mathrm{VO}_{2}$, rectal temperature and occurrence of ovulation in control (Group I), cafeteriafed (Group II), warm-adapted (Group III) and cold-adapted (Group IV) rats weighing $<60 \mathrm{~g}$ and treated with 5 i.u. PMSG on Day 27 of life

\begin{tabular}{lcccc}
\hline & Group I & Group II & Group III & Group IV \\
\hline Body wt (g) on Day 27 & $57 \cdot 1 \pm 0 \cdot 4$ & $57 \cdot 9 \pm 0 \cdot 30$ & $54 \cdot 5 \pm 1 \cdot 14$ & $56 \cdot 0 \pm 0 \cdot 50$ \\
Body wt (g) on Day 30 & $67 \cdot 4 \pm 0.84$ & $64 \cdot 9 \pm 1 \cdot 41$ & $64 \cdot 9 \pm 1 \cdot 67$ & $64 \cdot 3 \pm 0 \cdot 74$ \\
Resting VO & $12 \cdot 2 \pm 0 \cdot 3$ & $15 \cdot 3 \pm 0 \cdot 4^{* *}$ & & \\
$\quad\left(\mathrm{ml} / \mathrm{min} / \mathrm{w}^{0.75}\right)$ & $38 \cdot 1 \pm 0 \cdot 1$ & $38 \cdot 7 \pm 0 \cdot 1^{* * *}$ & $38 \cdot 8 \pm 0 \cdot 2^{* * *}$ & $14 \cdot 3 \pm 0 \cdot 3^{*}$ \\
Rectal temperature $\left({ }^{\circ} \mathrm{C}\right)$ & $6 / 21$ & $6 / 9^{*}$ & $11 / 15^{* * *}$ & $38 \cdot 1 \pm 0 \cdot 2$ \\
No. of rats ovulating & $7 \cdot 3 \pm 1 \cdot 9$ & $8 \cdot 8 \pm 1 \cdot 1$ & $8 \cdot 5 \pm 0 \cdot 72$ & $1 / 8$ \\
Ova/ovulating rat & &
\end{tabular}

Values are mean \pm s.e.m.

$\dagger$ In another set of immature rats there was an $11 \%$ reduction in resting $\mathrm{VO}_{2}$.

Values significantly different from those of Group I (controls): ${ }^{*} P<0.05,{ }^{* *} P<0.01,{ }^{* * *} P<0.001$.

\section{Discussion}

Previous work has shown that $77 \%$ (54/70) of rats weighing $>60 \mathrm{~g}$ on Day 27 of life ovulate 3 days after injection of PMSG, but only $14 \%(9 / 64)$ of animals weighing $<60 \mathrm{~g}$ ovulate, although the average number of ova per ovulating rat is similar for both groups (Wilson \& Endersby, 1979). In the present study, approximately $25 \%$ of the animals weighed $<60 \mathrm{~g}$ on Day 27 of age and these also showed reduced growth rates. This decreased growth may reflect natural genetic variation between animals, but could also result from early nutritional influences.

The reduced body size of rats $<60 \mathrm{~g}$ was not due to a disproportionate change in one particular component of the body, since composition (\% fat, water and protein) was similar for all animals, irrespective of body weight, although the total mass of each component was obviously lower in the smaller animals. It is therefore possible that the delayed ovulation in $<60 \mathrm{~g}$ rats might be due to a lower fat or protein mass, as suggested by Frisch et al. $(1975,1977)$ and Ramaley (1981), respectively. This effect could be advantageous to the animal since it would prevent conception until maternal energy stores were sufficient to support pregnancy and lactation.

Rats weighing $<60 \mathrm{~g}$ on Day 27 showed lower rates of oxygen consumption, which were apparent even when correction was made for body size. This may be due to a decreased food intake in the smaller animals, but the energy cost of fat and protein synthesis will also be depressed because of the slower growth rate. The lower rectal temperature of $<60 \mathrm{~g}$ rats may be related to their reduced heat production, and because of their lower body weight, the ratio of surface area to mass will be greater, thereby increasing heat losses.

These data show that $<60 \mathrm{~g}$ rats have a lower growth rate, metabolic and body temperature compared to $>60 \mathrm{~g}$ animals, but it is impossible to determine whether any of these factors are related to their poor responses to PMSG. Experiment 3 was therefore undertaken to manipulate body temperature and metabolic rate, and study the effects on ovulation in rats weighing $<60 \mathrm{~g}$.

Metabolic rate in homoiotherms increases as environmental temperature falls below the thermoneutral value, in order to maintain a constant body temperature. The thermoneutral value for the rat is approximately $29-30^{\circ} \mathrm{C}$, and at this temperature metabolic rate is minimal (Kleiber, 1961). Full development of non-shivering thermogenesis during cold exposure requires at least 7 days, whereas the inhibition of this thermogenesis when animals are kept at thermoneutrality is immediate (Smith \& Horwitz, 1969). For this reason our animals were exposed to cold for 10 days, whereas 4 days were considered more than sufficient for warm-adaptation. At $22^{\circ} \mathrm{C}$, heat production is slightly elevated and at $5^{\circ} \mathrm{C}$ it is markedly increased, largely due to non-shivering thermogenesis originating in brown adipose tissue. In Exp. 3, resting $\mathrm{VO}_{2}$ measured at thermoneutrality $\left(29^{\circ} \mathrm{C}\right)$ on Day 29 was elevated by $17 \%$ in rats chronically exposed to $5^{\circ} \mathrm{C}$ compared to 
controls maintained at $22^{\circ} \mathrm{C}$, but rectal temperature was similar for both groups. Animals housed at $30^{\circ} \mathrm{C}$ showed increased body temperatures, and we observed that, in a separate group of 29-dayold rats housed at $30^{\circ} \mathrm{C}$, resting $\mathrm{Vo}_{2}$ was $11 \%$ lower than that of controls housed at $22^{\circ} \mathrm{C}$. Raising ambient temperature significantly increased the incidence of ovulation in underweight rats injected with PMSG, whereas cold exposure, if anything, prevented ovulation in the $<60 \mathrm{~g}$ rats, although not in the $>60 \mathrm{~g}$ animals.

Feeding rats a varied and palatable diet causes increases in energy intake of 50-80\% compared to control animals maintained on pelleted stock diet (Rothwell \& Stock, 1979, 1982a). However, in young animals, this hyperphagia is accompanied by large compensatory increases in energy expenditure (diet-induced thermogenesis), which are similar to non-shivering thermogenesis and result from sympathetic stimulation of brown adipose tissue (Rothwell \& Stock, 1979, 1981, 1982b). Cafeteria feeding in young rats therefore has little or no effect on body weight gain but fat content is usually slightly increased. The cafeteria-fed rats in Exp. 3 gained weight at the same rate as stockfed controls, but showed significant increases in resting $\mathrm{VO}_{2}$ and body temperature, and a greater proportion of the cafeteria-fed rats ovulated after PMSG.

The results of Exp. 3 therefore indicate that the reduced ovulation of rats weighing $<60 \mathrm{~g}$ cannot be related to their lower metabolic rate, since raising $\mathrm{VO}_{2}$ by exposure to cold did not stimulate ovulation, whereas rats housed at $30^{\circ} \mathrm{C}$ showed an increased ovulation in spite of a decline in $\mathrm{VO}_{2}$. However, ovulation may be related to fat content or body temperature. Frisch et al. (1975) have shown that rats maintained on a high fat diet have an increased body fat content and ovulate at an earlier age than controls. Similarly, cafeteria feeding increases body fat content (Rothwell \& Stock, 1979) and enhances ovulation in rats $<60 \mathrm{~g}$. Body temperature is lower in the $<60 \mathrm{~g}$ rats, and raising temperature by cafeteria feeding or housing at $30^{\circ} \mathrm{C}$ for 4 days stimulated ovulation, although acute $(24 \mathrm{~h})$ exposure to $30^{\circ} \mathrm{C}$ does not affect the responses to PMSG in $<60 \mathrm{~g}$ rats $(1 / 5$ ovulated).

Rats weighing $<60 \mathrm{~g}$ and treated with PMSG can be induced to ovulate when given single injections of growth hormone, corticosterone or triiodothyronine on Day 29 (unpublished results). These hormones do not affect LH levels in PMSG-treated rats weighing $<60 \mathrm{~g}$ but do raise body temperature, and a high ambient temperature stimulates the release of these hormones (Marple, Aberle, Forrest, Blake \& Judge, 1972; Parkhie \& Johnson 1973). Since $<60 \mathrm{~g}$ animals have a pleiomorphic form of $\mathrm{LH}$, it is possible that a raised body temperature or one of these hormones is required to convert the pleiomorphic $\mathrm{LH}$ to an active form necessary to stimulate follicular rupture and ovulation. This possibility, and the effects of temperature and body composition on spontaneous ovulation in normal rats, are presently being investigated.

This work was supported by a Medical Research Council project grant to C.A.W., and a Royal Society Fellowship to N.J.R. We are grateful to the members of the Department of Child Health and Clinical Research Laboratories, St George's Hospital, for their advice and technical help.

\section{References}

Frisch, R.E. (1979) Fatness and the onset and maintenance of menstrual cycles. In Psychoneuroendocrinology in Reproduction, pp. 253-262. Eds L Zichella \& P. Pancheri. Elsevier/North-Holland Biomedical Press, Amsterdam.

Frisch, R.E. (1980) Pubertal adipose tissue: is it necessary for normal sexual maturation? Evidence from the rat and human female. Fedn Proc. Fedn Am. Socs exp. Biol. 39, 2395-2400.

Frisch, R.E., Hegsted, D.M. \& Yoshinaga, K. (1975) Body weight and food intake at early estrus of rats on a high-fat diet. Proc. natn. Acad. Sci. U.S.A. 72, 41724176 .
Frisch, R.E., Hegsted, D.M. \& Yoshinaga, K. (1977) Carcass components at first estrus of rats on high-fat and low-fat diets: body water, protein and fat. Proc. natn. Acad. Sci. U.S.A. 74, 379-383.

Gentry, R.T. \& Wade, G.N. (1980) Effect of the interaction of body weight and daily estradiol benzoate injections on the onset of estrous cyclicity in rats. Biol. Reprod. 23, 733-736.

Glass, A.R., Harrison, R. \& Swerdloff, R.S. (1976) Effect of undernutrition and amino acid deficiency on the timing of puberty in rats. Pediat. Res. 10, 951955. 
Glass, A.R., Dahms, W.T. \& Swerdloff, R.S. (1979) Body fat at puberty in rats: alteration by changes in diet. Pediat. Res. 13, 7-9.

Kleiber, M. (1961) The Fire of Life. Wiley \& Sons, New York.

Marple, D.N., Aberle, E.D., Forrest, J.C., Blake, W.H. \& Judge, M.D. (1972) Effects of humidity and temperature on porcine plasma adrenal corticoids, ACTH and growth hormone levels. J. Anim. Sci. 34, 809-811.

Merry, B.J. \& Holehan, A.M. (1979) Onset of puberty and duration of fertility in rats fed a restricted diet. $J$. Reprod. Fert. 57, 253-259.

Miller, D.S. \& Payne, P.R. (1959) A ballistic bomb calorimeter. Br. J. Nutr. 13, 501-504.

Oser, B.L. (Ed.) (1965) Hawk's Physiological Chemistry, 14th edn, pp. 1216-1217. McGraw-Hill, New York.

Parkhie, M.R. \& Johnson, H.D. (1973) Hypothalamic growth hormone releasing factor: release and synthesis after exposure to a high ambient temperature. Proc. Soc. exp. Biol. Med. 142, 311-315.

Ramaley, J.A. (1981) Puberty onset in males and females fed a high fat diet. Proc. Soc. exp. Biol. Med. 166, 294 296.

Rothwell, N.J. \& Stock, M.J. (1979) A role for brown adipose tissue in diet-induced thermogenesis. Nature, Lond. 281, 31-35.

Rothwell, N.J. \& Stock, M.J. (1981) Influence of noradrenaline on blood flow to brown adipose tissue in rats exhibiting diet-induced thermogenesis. Pflügers Archiv. 389, 237-242.

Rothwell, N.J. \& Stock, M. J. (1982a) Effects of feeding a palatable 'cafeteria' diet on energy balance in young and adult lean (+/?) Zucker rats. Br. J. Nutr. 47, 461471.

Rothwell, N.J. \& Stock, M.J. (1982b) Energy expenditure of 'cafeteria'-fed rats determined from measurements of energy balance and indirect calorimetry. $J$. Physiol., Lond. 328, 371-377.

Smith, R.E. \& Horwitz, B.A. (1969) Brown fat thermogenesis. Physiol. Rev, 49, 330-425.

Stock, M.J. (1975) An automatic, closed-circuit oxygen consumption apparatus for small animals. J. appl. Physiol. 39, 849-850.

ter Haar, M.B. \& Wilson, C.A. (1978) Evidence for pleiomorphism of luteinizing hormone in peripubertal female rats. J. Endocr. 79, 133-134.

Wilen, R. \& Naftolin, F. (1978) Pubertal food intake and body length, weight and composition in the feedrestricted female rat: comparison with well fed animals. Pediat. Res. 12, 265-267.

Wilson, C.A. \& Endersby, C.A. (1979) The stimulatory effect of 5HT and the role of the paraventricular nucleus on PMS induced ovulation in the immature rat. Neuroendocrinology 28, 415-424.

Received 25 January 1983 